\title{
Reshaping International Relations: Theoretical Innovations from Africa*
}

\author{
Karen Smith \\ University of Cape Town, South Africa and Leiden University, the Netherlands
}

\begin{abstract}
This article is based on the assumption that theoretical contributions from the global South - and in this case, from Africa, do not need to be radically different from existing theories to constitute an advancement in terms of engendering a better understanding of international relations. Reinterpretations or modifications of existing frameworks and the introduction of new concepts for understanding are equally important. This is an accepted practice in mainstream $I R$, where existing theories are constantly amended and revisited. One need only consider the various incarnations of realist thought.While adaptations and conceptual innovations by western scholars are recognised as legitimate and adopted into the canon of theory, this is not always the case with similar contributions emerging from outside of the West. This article will examine three examples of such contributions by African scholars. ${ }^{l}$ The first group of scholars reinterpreted the concept of "middle power," arguing that there are specific characteristics that set emerging middle powers like South Africa apart from traditional middle powers. The second, Deon Geldenhuys, developed the concept "isolated states" and generated a novel analytical framework to categorise states based on indicators of isolation. Finally, Thomas Tieku draws on the African worldview of ubuntu in calling for the state to be reconceptualised in a collectivist, societal way. It is hoped that these examples will illustrate that there are theoretical innovations emerging from the Global South that can assist us in not only better understanding international relations in a particular part of the world, but can in fact provide greater insights into the field as a whole.
\end{abstract}

Keywords: South Africa, middle power, emerging states, ubuntu, homegrown theorizing, non-Western IR

\section{Introduction}

Much has been written in recent years about the Western-centric nature of existing International Relations (IR) theory, the inapplicability of 'commonsense' concepts to the Global South, and the need for the field of IR to engage with voices from outside the West. What started off as calls coming from the periphery of the field have now penetrated the

\footnotetext{
Karen Smith, PhD, Lecturer, Institute for History, Leiden University, the Netherlands. E-mail: Karen.smith@uct.ac.za.

*Upon the request of the author, certain changes were made in this version.

1 Deon Geldenhuys and the first group of scholars (van der Westhuizen, Nel, Schoeman and Jordaan) are South African, or in the case of Taylor, were based in South Africa, while Thomas Tieku is Ghanaian. The choice of scholars is not deliberately skewed towards South African scholars, but is based on the work of African scholars with whom I am most familiar. I intend to build on this initial attempt at identifying African theoretical contributions by identifying similar work from other parts of Africa.
} 
US-based International Studies Association (ISA), reflected in the 2015 annual convention theme: "Global IR and Regional Worlds". This increased interest, no doubt, stems partly from a growing sense of anxiety in the West about changes occurring in the international system, linked to the rise of new actors whose behaviour and motivations existing theories are not able to make sense of.

These criticisms have also been accompanied by calls for greater inclusion of contributions from outside of the West. Unfortunately, these calls have not been met with great success. While some journal and book editors and conference organisers are making a concerted effort to include the work of scholars from outside of the USA and Europe, many have been disillusioned by the lack of response they have received. Relatedly, scholars like Tickner and Waever and Tickner and Blaney who set out a decade ago on a project to discover how IR is taught, researched and practised in the different parts of the world found, to their disappointment, that IR in disperse parts of the world does not seem to be all that different. ${ }^{2}$ Is Vale's comment about the South African IR community - namely that scholars seemed to be engaged in "an enterprise which, generally speaking, displays little imagination and almost no conceptual adventure"3 - still applicable, also to other parts of the Global South?

Nkiwane asked whether the situation can be explained on the basis that "Africa has little to contribute to IR, or because the power dynamics of the discipline are such that African voices are not heard?"4 I have previously argued, in line with other scholars, that the answer to this question lies in both. While external factors prevent the expansion of IR knowledge to include contributions from the developing world, internal or domestic factors inhibit the creation and dissemination of this knowledge. As these have been discussed at length elsewhere they will not be revisited here. ${ }^{5}$

But is this disappointment really warranted? What is it that we are expecting to emerge from the Global South? A new theory to challenge realism? A groundbreaking new way of understanding IR that will change the way scholars and policymakers think?

In making the claim that not much innovative theoretical work has come out of the Global South, and Africa in particular, one has to be clear about what exactly is meant by a theoretical contribution or innovation. This means starting with a definition of theory as it applies to IR. In his 1967 article titled "What is a Theory of International Relations?" Raymond Aron contended that theory can have two meanings: first, it can be "contemplative knowledge... the equivalent of philosophy". ${ }^{6}$ Secondly, a theory can be "a hypothetical, deductive system consisting of a group of hypotheses whose terms are strictly defined and whose relationships between terms (or variables) are most often given a mathematical form". ${ }^{7}$ Mallavarapu defines theories on the basis of their expectations. According to him, theories involve a degree of abstraction, a degree of generalisation, and seek to explain. ${ }^{8}$

Arlene B. Tickner and Ole Wæver, eds., International Relations Scholarship around the World (London and New York: Routledge, 2009); Arlene Tickner and David Blaney, eds., Thinking International Relations Differently (London: Routledge, 2012).

3 Peter Vale, "International Relations in Post-apartheid South Africa: Some Anniversary Questions," Politikon 31, no. 2 (November 1, 2004): 240, doi:10.1080/0258934042000280751.

4 Tandeka Nkiwane, "Africa and International Relations: Regional Lessons for a Global Discourse," International Political Science Review 22, no. 3 (2001): 280.

5 See, for example, Amitav Acharya and Barry Buzan, "Why is there no non-Western IR theory? An Introduction," International Relations of the Asia-Pacific 7, no. 3 (2007): 287-312; Karen Smith, "Obstacles to the Development of IR Theory in the Developing World: The Case of South Africa," Africa Review 2, no. 1 (2010): 65-80.

6 Raymond Aron, "What Is a Theory of International Relations?" Journal of International Affairs 21, no. 2 (1967): 186.

Aron, "What Is a Theory," 186.

8 Siddharth Mallavarapu, "Theories of International Relations," in International Relations: Perspectives for the Global South, ed. Bhupinder Chimni and Siddharth Mallavarapu (New Delhi: Dorling Kindersley, 2012), 5. 
With regards to advancing IR theory through contributions from outside of the West, the debate continues about whether universalist IR theories are at all possible, or whether the way forward is to develop regional-specific approaches (for example, the development of an IR theory with Chinese characteristics). Cunningham-Cross notes how in calls by Chinese scholars for greater innovation in Chinese approaches to IR theory, the emphasis has been on newness, with innovation meaning "coming up with something that is not only new but also distinctive". ${ }^{9}$ She continues that newness is measured against certain ostensibly Western markers and originality can only exist where there is evidence of a clear distinction from the so-called Western theory that preceded it". ${ }^{10}$

\section{Theoretical Innovation or Not?}

Our excitement about the possibilities that exist outside of the West should also be tempered by the realisation that ground-breaking theoretical innovations are simply not that common. If we allow ourselves to think more generally about theoretical innovation it can, in the words of Mittelman mean "creative imagination in the production of new knowledge". ${ }^{11}$ There must be a recognition that there are different levels of theoretical innovation, not necessarily to the extent of developing new theory but also through theory and concept adaptation. Gill writes, "An innovation introduces something new - a new method, a new theory, a new perspective - in ways that have some practical effect on the way that we may think about and potentially act in the world". Importantly, he emphasises that "Often this simply involves the act of writing, synthesising, codifying or clarifying ideas current for over half a century...or else rearticulating existing Republican arguments in different political contexts". ${ }^{12}$ Bilgin, drawing on the work of post-colonial scholars like Homi Babha, remains tremendously insightful with regard to reminding us that we should not expect to find only difference in the non-West. Identifying similarities and instances of mimicry with some adaptation - in other words, doing world politics in a "seemingly "similar" yet unexpectedly "different" way' can be equally valuable. ${ }^{13}$ For example, adapting theory to the local context through reinterpretations or modifications of existing frameworks - what I have referred to as "reinterpreting old stories" in an earlier paper ${ }^{14}$ and the introduction of new concepts for understanding are equally important. This is an accepted practice in mainstream IR, where existing theories are constantly amended and revisited. One need only consider the various incarnations of realist thought. While adaptations by western scholars are recognised as legitimate and adopted into the canon of theory, this is not always the case with adaptations emerging from outside of the West. For example, Mohammed Ayoob's notion of what he calls "subaltern realism" 15 has remained on the fringes of the field and has not been recognised as constituting a significant elaboration of realist thinking. Disregarding such contributions as not important or radical enough denies agency to scholars who are contributing in ways that can enrich our understanding of international relations. South African scholars' revisiting of the notion of "middle power" serves as a case in point.

9 Linsay Cunningham-Cross, "The Innovation Imperative: Chinese International Relations Research and the Search for a 'Chinese School'," (unpublished paper, n.d), 2.

10 Cunningham-Cross, "The Innovation Imperative," 3.

11 James H. Mittelman, "Rethinking Innovation in International Studies: Global Transformation at the Turn of the Millennium," in Innovation and Transformation in International Studies, ed. S. Gill and J. H. Mittelman(Cambridge, UK: Cambridge University Press, 1997), 249.

12 Stephen Gill, "Transformation and Innovation in the Study of World Order," in Innovation and Transformation in International Studies, ed. Stephen Gill and James H. Mittelman (Cambridge: Cambridge University Press, 1997$), 9$.

13 Pinar Bilgin, “Thinking Past 'Western' IR?” Third World Quarterly 29, no. 1 (2008): 6, doi:10.1080/01436590701726392.

14 Karen Smith, "Has Africa Got Anything to Say? African Contributions to the Theoretical Development of International Relations," The Round Table 98, no. 402 (2009): 269-84.

15 Mohamed Ayoob, "Subaltern Realism: International Relations Theory Meets the Third World," in International Relations Theory and the Third World, ed. Stephanie G. Neuman (Houndsmills: Macmillan, 1998), 31-54. 


\section{South African Contributions to the Adaptation of the Middle Power Concept}

In the late 1990s and early 2000s, a number of South African scholars published articles in which they interrogated the "middle power" concept that had become increasingly popular as a way to understand South Africa's foreign policy. They based their work on the existing literature on middle powers in IR that had been developed and popularised predominantly by scholars like Andrew Cooper and Robert Cox, from another recognised middle power, Canada. As the concept - initially reserved for "traditional middle powers" like Canada, Australia, Norway and Sweden - was increasingly being applied to states like South Africa, Brazil and Turkey, it appeared to be losing some of its analytical value. Scholars like van der Westhuizen, Nel, Taylor and van der Westhuizen, Schoeman and particularly Jordaan subsequently made an important contribution to the literature on middle powers by developing the concept through providing greater analytical clarity, and specifically making the distinction between traditional and new, emergent or emerging middle powers. ${ }^{16}$

While South Africa had been referred to in the literature as both an "emerging power" 17 and a "middle power," 18 van der Westhuizen first writes about "South Africa's emergence as a middle power" and Schoeman was the first to explicitly examine the meaning of the concept "emerging middle power" in relation to South Africa. ${ }^{19}$ Nel, Taylor and van der Westhuizen, in exploring South Africa's commitment to multilateralism, highlight what they refer to as a "deficiency in the literature to distinguish between traditional or established middle powers in the industrialized Western world and emerging middle powers in the South". ${ }^{20}$ They set out five preliminary suggestions for distinguishing between traditional and emerging middle powers.

Building directly on Cooper and Nel et al., Jordaan sets out to further refine the conceptual distinction and to develop a schematic to distinguish between emerging and traditional middle powers on the basis of their constitutive and behavioural differences. ${ }^{21}$ According to Jordaan his motivation was to propose an analytical solution to the problems Schoeman and Nel et al had come up against in their attempts to distinguish between traditional and emerging middle powers. ${ }^{22}$ While recognising the similarities between middle powers, namely that they "conform to the middle power role by their legitimising and stabilising actions that enable a smother functioning of the global order", ${ }^{23}$ he emphasises that more differences exist than is recognised by the existing literature. Under constitutive differences he includes democratic tradition, time of emergence as middle powers, position in the world economy, domestic distribution of wealth, regional influence, and origins of perceived neutrality. Under behavioural differences, regional orientation, attitude to regional integration and cooperation, nature of actions to effect deep global change, and purpose of international identity construction are listed. For example, with regard to their position in the global

${ }_{16}$ Janis van der Westhuizen, "South Africa's Emergence as a Middle Power," Third World Quarterly 19, no. 3 (1998): 435-55; P. Nel, I. Taylor, and J. van der Westhuizen, "Multilateralism in South Africa's Foreign Policy: The Search for a Critical Rationale," Global Governance 6, no. 1 (2000): 43-60; Maxi Schoeman, "South Africa as an Emerging Middle Power," African Security Review 9, no. 3 (2000): 47-58; Eduard Jordaan, "The Concept of a Middle Power in International Relations: Distinguishing Between Emerging and Traditional Middle Powers," Politikon 30, no. 1 (2003): 165-81.

${ }^{17}$ See, for example, Garth Le Pere, "South Africa - an 'Emerging Power'?" Global Dialogue 3, no.1 (1998): 1-2.

${ }_{18}$ Hussein Solomon, "South African Foreign Policy and Middle Power Leadership," in Fairy Godmother, Hegemon or Partner? In Search of a South African Foreign Policy, ed. Hussein Solomon (Halfway House: Institute for Security Studies Monograph Series, 1997).

19 van der Westhuizen, "South Africa's Emergence"; Schoeman, "South Africa".

20 Nel, Taylor, and van der Westhuizen, "Multilateralism in South Africa's Foreign Policy," 46. (emphasis in original)

21 Jordaan, "The Concept of a Middle Power," 168.

22 Eduard Jordaan, phone interview by the author, March 15, 2017.

23 Jordaan, "The Concept of a Middle Power," 178 
economy (a constitutive difference), he contends that while traditional middle powers are located in the core, emerging middle powers are in the semi-periphery. This has important implications for their consequent behaviour and overall foreign policy orientation, with the former engaging in legitimising behaviour, while the latter tend towards the reform of global economic rules and structures. This reformist tendency, rather than a more fundamental transformist approach exhibited by emerging middle powers can be explained by the fact that, as semi-peripheral economies, these states still have a competitive advantage over states in the periphery, an advantage they do not wish to lose through a large-scale overhaul of the system. ${ }^{24}$ Another significant difference between traditional and emerging middle powers has to do with the regional dimension. While the former have little interest in their immediate region and regional integration initiatives, the latter have a much stronger regional orientation and are often also considered as regional powers. These are important differences in foreign policy behaviour that are obscured by reliance on the original concept of "middle power" but usefully highlighted by Jordaan's innovation of distinguishing between "traditional" and "emerging" middle powers.

The work of these scholars, and Jordaan's in particular, is a useful illustration of how an existing concept can be adapted in order to make it more applicable to a particular context in this case, understanding the role that South Africa was playing in the world. Significantly, however, the modification applies to a much wider group of states that all fit the criteria of "emerging middle powers". Its conceptual value is evidenced by the fact that, despite being published in the internationally unknown journal Politikon: South African Journal of Political Studies, Jordaan's article has been cited 187 times, and remains the second most viewed and second most cited article published in the journal (Politikon, 2016). This is a clear indication of the broader significance of his theoretical innovation.

\section{Geldenhuys' Conceptual Refinement}

In a similar vein, South African scholar Deon Geldenhuys" work on what he calls "isolated states" addresses a gap in the existing IR literature by providing us with analytical tools to study states that have been ostracised by the international community. As he notes, the notion of isolated states is a peculiar phenomenon in an increasingly interconnected international system. In his 1990 book, Geldenhuys emphasises why his work on isolated states is not just of importance to an isolated state like South Africa when he argues "While South Africa may indeed be the world's foremost ostracised state today, it is not alone in this league. Notwithstanding the many unique features of South Africa's isolation, it is part of a wide international problem". ${ }^{25}$

He distinguishes between pariah or ostracised states, and those that voluntarily withdraw from international relations, in other words externally enforced versus self-imposed isolation. He defines isolation as "either a deliberate policy, voluntarily and unilaterally pursued by a state over a period of time, of restricting its international interactions and thereby withdrawing to a greater or lesser degree from 'normal' international relations (self-isolation or isolationism) or a deliberate policy pursued by two or more states against another, over a period of time, aimed at severing or curtailing the latter's international interactions against its will (enforced isolation)" ${ }^{26}$

\footnotetext{
24 Jordaan, "The Concept of a Middle Power," 176.

25 Deon Geldenhuys, Isolated States: A Comparative Analysis (Cambridge: Cambridge University Press, 1990$), 2$.

26 Geldenhuys, Isolated States, 6 (emphasis in original).
} 
He goes on to develop an analytical framework to measure the extent of a state's isolation, involving a set of thirty indicators that he groups into four areas of isolation, namely: politicaldiplomatic, economic, military and socio-cultural. He also cautions that not all 30 indicators are of equal importance, and that they should be employed together with various other structural and functional considerations. These include the specific target, means, origins, objectives, time and results of isolation. He then applies his framework in a comparative study focusing on four main case studies, namely China, Israel, Chile and South Africa.

The notion of ostracism or isolation of states remains a highly topical issue. Some states who, historically, were the target of ostracism by the Western international society but were subsequently integrated to a certain extent, find themselves in a familiar situation today. Geldenhuys notes the examples of Russia and Turkey as historical examples of ostracism which, at the time of publication in 1990, "either no longer exists or their current level of isolation is generally well below that of Israel, Taiwan, Chile and South Africa" ${ }^{27}$ Twentyseven years later, it seems Russia and Turkey would again make for interesting case studies of isolated states. Geldenhuys notes how Russia has long been the target of ostracist thinking by Europeans, citing the $17^{\text {th }}$ century internationalist theories of the duc de Sully and William Penn, which expressed reservations about including Russia in an international organisation. ${ }^{28}$ Similarly, he notes how throughout history, the Ottoman Empire was regarded as a threat to Europe and various plans were continuously develop to exclude it from European integration efforts.

Although his work is largely descriptive, Geldenhuys makes an important contribution with regard to refining the conceptual differentiation between terms like isolation, alienation, obscurity, seclusion and isolationism. More significantly, however, he provides students of IR with an analytical framework by which to measure the international isolation of states.

Although Geldenhuys did not comment on this directly, it is clear that the phenomenon of isolation, exclusion, and ostracism he studies has direct bearing on recent debates about the marginalisation of the non-West in the field of International Relations. In almost all cases, states are isolated as a result of not meeting particular criteria - decided by Western states that allow for inclusion, acceptance and participation in international society.

In 2004, Geldenhuys published another book on states that are regarded as outcasts by the international community. This time, his focus was on "deviant states". In a similar vein to his book on isolated states, his starting point is that the existing terms used in the mainstream literature to refer to those states who "behave[d] badly" 29 - such as pariah, outcast or rogue - were analytically weak as they did not have "a fixed meaning nor any standing in international law" and therefore failed to offer "a structure for studying the full spectrum of offensive behaviour by states and non-state actors". ${ }^{30} \mathrm{He}$ then goes on to develop an analytical framework of deviance, drawing on sociological theories of deviance to outline three basic elements of deviant behaviour, namely social codes, rule breakers and rule defenders. As was the case with his isolated states book, he subjects his framework to rigorous empirical testing. While Geldenhuys' theoretical work on isolated states and deviant conduct has been cited 148 and 33 times respectively (according to Google Scholar) his seminal book on South African foreign policy, The Diplomacy of Isolation: South African Foreign Policy Making (1984) has been cited 240 times. ${ }^{31}$ There are numerous possible explanations - one being that

27 Geldenhuys, Isolated States, 28.

28 Geldenhuys, Isolated States, 29.

29 Deon Geldenhuys, Deviant Conduct in World Politics (New York: Palgrave Macmillan, 2004), 11.

${ }^{30}$ Geldenhuys, Deviant Conduct, 12.

31 Deon Geldenhuys, The Diplomacy of Isolation: South African Foreign Policy Making (Johannesburg: Macmillan South Africa, 1984) 
the latter was published 6 and 20 years before his other work. It could also be explained by the point made by scholars like Bajpai that in the global distribution of academic labour, ${ }^{32}$ scholars in the Global South are often relegated to regional experts whose value lies in their capacity to provide empirical data for the application of existing (Western) frameworks. It is also interesting to note that, when one disaggregates the citations for Isolated States, the book is cited mainly by South African scholars or international scholars working on South Africa. Perhaps, had Geldenhuys been an American scholar based at a prestigious American institution, his work would have had a much greater impact.

\section{The Collectivist Worldview: An Ubuntu Alternative to International Relations}

Another scholar who makes a significant theoretical contribution in shedding light on the foreign policy of African states, Thomas Tieku, not only refines existing frameworks or refines concepts, but also incorporates indigenous worldviews into this analysis. ${ }^{33}$ In an attempt to develop an alternative explanation for the behaviour of African states, Tieku draws on the idea of African societies as collectivist to develop understandings of, amongst others, the African solidarity norm. The notion of an African solidarity norm, which discourages African leaders from disagreeing with each other in public and from defying continental consensus on issues was referred to by scholars such as Mazrui and Clapham. ${ }^{34}$

In an effort to explain the motivations for this behaviour, Tieku, a Ghanaian scholar, bases his argument on the notion that the predominantly individualist ontology employed by scholars of international relations fails to incorporate practices based on a more collectivist understanding, such as consensual decision-making. ${ }^{35}$ He highlights some of the problems with an individualist approach, one of which is that it neglects group identity. This is in contrast to collectivist societies, where group membership and obligations are paramount. ${ }^{36}$ When these assumptions are transferred to the state, we can only understand the state as an independent, egotistical actor that, he argues, results in a limited understanding of state behaviour. Specifically, he argues that the individualist ontology prevalent in Western IR "has undermined our understanding of the international politics of collectivist social entities such as those in Africa". ${ }^{37}$

A collectivist understanding of Africa's international relations is manifested in the perspective of ubuntu. It can be regarded as an indigenous worldview, common to southern African societies, and found in different forms across the rest of the African continent. While the term ubuntu comes from the Nguni language family, variants of it exist in many sub-Saharan African languages. It is difficult to translate into English, with "collective personhood" being the most direct translation. It refers to the idea that

[The individual] owes his existence to other people...He is simply part of the whole... Whatever happens to the individual happens to the whole group, and whatever happens to the whole group happens to the individual $[\ldots] .{ }^{38}$

32 Kanti Bajpai, “Obstacles to Good Work in Indian International Relations,” International Studies 46, no. 1-2 (2009): 109-28.

33 Thomas Kwasi Tieku, "Collectivist Worldview: Its Challenge to International Relations," in Africa and International Relations in the Twenty-First Century, ed. Fantu Cheru, Timothy Shaw, and Scarlett Cornelissen (Basingstoke: Palgrave Macmillan, 2012), 36-50.

${ }^{34}$ Ali A. Mazrui, "On the Concept of "We are all Africans," American Political Science Review 57, no. 1 (1963): 88-97; Ali Mazrui, Towards a Pax Africana: A Study of Ideology and Ambition (London: Wakefield \& Nicolson, 1967); Christopher Clapham, Africa and the International System: The Politics of State Survival (Cambridge: Cambridge University Press, 1996).

35 Tieku, "Collectivist Worldview," 37.

36 Tieku, "Collectivist Worldview," 41.

37 Tieku, "Collectivist Worldview," 41.

${ }_{38}$ Mbiti, 108-9, quoted in Rob Gaylard, "Welcome to the World of Our Humanity": (African) Humanism, ubuntu and Black 
While much has been written about ubuntu, particularly with reference to conflict resolution, peacebuilding and human rights, ${ }^{39}$ it remains on the fringes of scholarly analysis in IR. Scholars of South Africa's foreign policy have had to take note of it after the term appeared in the title of the country's 2011 foreign policy white paper: "Building a better world: the diplomacy of ubuntu" ${ }^{40}$ As discussed in previous work, ${ }^{41}$ the concept of ubuntu may help us to understand how both states and non-state actors in Southern African relate to one another.

It is important to point out an important caveat in employing this term as representative of African communities: in light of the apparent disconnect between this concept and much of what is currently occurring on the African continent, it is often dismissed as utopian and not reflective of reality. However, while the principles underlying ubuntu are undoubtedly under tremendous pressure throughout Africa, as a result of urbanisation, conflict, and so forth, this does not invalidate its potential to contribute to our understanding of IR.

In applying a collectivist understanding to Africa's international relations, Tieku argues that this has important implications for thinking about concepts like national interest. If the state does not primarily see itself as an independent actor pursuing its own narrow interests, seemingly irrational behaviour by African states can more easily be understood. He describes three features arising from a more collectivist approach, namely consensual decision-making, group-think and the Pan-African solidarity norm. ${ }^{42}$ Consensus-based decision-making is encapsulated in former Tanzanian president Julius Nyerere's statement, "We talk until we agree". ${ }^{43}$ In practice, this means that decisions by the African Union's Peace and Security Council about whether or not to intervene in a conflict on the continent has to be reached through consensus.

Tieku regards the Pan-African solidarity norm as "a widespread belief among African ruling elites that the proper and ethically acceptable behaviour of Africa's political elites is to demonstrate a feeling of oneness and support towards other African leaders, at least in public". ${ }^{44} \mathrm{He}$ highlights the practical implications of continued adherence to this norm, which include that decisions to intervene are made on the basis of consensus, there is a strong preference for soft tools, and that African Union (AU) members are not allowed to criticise offending states in public. ${ }^{45}$ This sheds light on African states' show of solidarity with Sudanese President al-Bashir - which involves their refusal to arrest him despite calls by the International Criminal Court (ICC). Attempts by the AU to engage Muammar Gaddafi in a negotiated solution before the United Nations (UN) decision to authorise North Atlantic Treaty Organisation (NATO) airstrikes is another illustration. Former South African president Thabo Mbeki's handling of the crisis in Zimbabwe also remains a relevant case in point. He consistently deployed so-called "quiet diplomacy", and - despite significant

\footnotetext{
South African Writing," Journal of Literary Studies 20, no. 3-4 (2004): 268-69.

39 See, for example, Tim Murithi, "A Local Response to the Global Human Rights Standard: The 'Ubuntu' Perspective on Human Dignity," Globalization, Societies and Education 5, no. 3 (2007): 277-86.

${ }^{40}$ While the term appears in the title of the foreign policy document, nowhere in the text is a definition provided of what exactly is meant by it.

${ }^{41}$ Karen Smith, "Contrived Boundaries, Kinship and Ubuntu: A (South) African View of the 'International'," in Thinking International Relations Differently, ed. A. Tickner and D. Blaney (London: Routledge, 2012), 301-21.

42 The notion of the Pan-African solidarity norms builds on work by Clapham (1996) and Mazrui $(1963,1967)$.

43 Quoted in Heinz Kimmerle, "Ubuntu and Communalism in African Philosophy and Art," Rozenberg Quarterly, September 2011, accessed August 10, 2016, http://rozenbergquarterly.com/ubuntu-and-communalism-in-african-philosophy-and-art/, 3.

${ }_{44}$ Thomas Kwasi Tieku, "Solidarity Intervention: Emerging Trends in AU's Interventions in African Crisis" (speaking notes for the workshop on Africa International: Agency and Interdependency in a Changing World, Chatham House, London, UK, October 9 , 2009), 3 .

${ }^{45}$ Tieku, "Solidarity Intervention," 4.
} 
international pressure to the contrary - remained unwilling to publicly criticize the Mugabe regime's human rights abuses. Whilst, from a western, individualist understanding, these public displays of solidarity by African states seem somewhat irrational, if approached from a collectivist worldview, they make much more sense. The preference for negotiated solutions to conflict and refusal to condemn human rights abuses by other African states is very much in line with notions of African collectivism. Tieku contends that understanding this can assist the rest of the international community in responding appropriately to African states. Importantly, however, he also emphasises that the collectivist ideas and practices he outlines are not only found in Africa. ${ }^{46}$ This is significant, in that what he calls "[t]heir omission from the analytical tools of IR" has not only impoverished our understanding of the behaviour of African states, but of IR in general. ${ }^{47}$ Drawing on indigenous concepts like ubuntu can help to explain not only the behaviour of African states, but in shifting our focus from an individualist to a collectivist ontology, can illuminate the dynamics at play in global governance more broadly. After all, an important motivation for exploring African and other non-Western readings of existing IR concepts is to gain new insights that can enrich our understanding of international relations in general.

While Tieku's work on the African Union is frequently cited, his chapter on a collectivist worldview (published in 2012) has only been cited six times. This could partly be due to the fact that it was published as a book chapter, but may also tell us something about the interest in such alternative understandings of international relations.

\section{Conclusion}

This paper has tried to move beyond the now widely accepted criticism that existing IR theories are inadequate in understanding the full diversity of international relations, and fail in particular when trying to explain dynamics in the Global South. In exploring potential theoretical contributions from Africa, it has also tried to avoid being hamstrung by grand ambitions of innovative theorising and a perpetual search for difference. Instead, the contention is that even seemingly minor adaptations of existing concepts or frameworks constitute significant contributions to the development of the field of IR. Despite the obvious value of these contributions, the issue of recognition remains a challenge. Ironically, it is not just gatekeepers in the core that do not recognise adaptations as making significant contributions. Commentators in the Global South, too, disregard adaptation as an inferior practice as it still uses existing knowledge as its foundation, thus legitimising what is regarded by many as illegitimate forms of knowledge imposed on the developing world through colonialism.

Having considered some of the advantages of non-western theorising, it is only appropriate to also point out the potential pitfalls. Perhaps the most dangerous is the tendency towards nativism, the assumption that what is, for example, African or Asian or from the Global South, is necessarily superior, different, closer to the truth, or more radical than Western knowledge.

Recent calls for decolonising knowledge - while founded on legitimate concerns about what are perceived as continuing reliance on Western or colonial authors and ways of thinking about the world - have in some cases also been accompanied by a call for the rejection of all existing Western knowledge.

\footnotetext{
${ }^{46}$ Tieku, "Collectivist Worldview," 49.

47 Tieku, "Collectivist Worldview," 49.
} 
This approach is also reflected in renewed calls by some South African students to 'decolonise' or 'Africanise' the knowledge that they are exposed to at universities. The insistence on Africanist approaches is itself founded on dangerous notions of nativism and exclusivity that assume that African knowledge is necessarily superior, different, or more radical than western knowledge. These calls for a radical purging of colonial/Western influence are arguably impossible to achieve in practice, given the interconnected nature of knowledge in a globalised world. Bilgin and others have highlighted the ways in which knowledge sharing has always been an interactive process, and the difficulties in determining what is Western, colonial, imported knowledge versus what is truly autochtonous. ${ }^{48}$ Acknowledging the influence that colonial practices have had in imposing certain forms of knowledge does not mean that we should not also acknowledge the fact that knowledge has never travelled exclusively in a uni-directional manner. Knowledge creation and dissemination has occurred through imposition, but also through mutual exchange - whether deliberate or not, in parallel, in contestation, and in mimicry. Such demands are in stark contrast with the argument made in this paper, namely that knowledge creation can and should not be an isolated endeavour but that building on existing knowledge is essential to the broader project. By rejecting these calls, the claim is not that the Western canon does not suffer from severe shortcomings. It also does not imply that much of Western scholarship is not biased, shortsighted and simply illegitimate in its assumptions of universality. We cannot claim this, however, if we do not engage with it, in all its plurality, and draw our own conclusions.

One of the leading figures of African postcolonialist thinking, Frantz Fanon, was heavily influenced by a diversity of thinkers - most of them western. This, of course, does not mean that Fanon uncritically internalised these ideas and made them his own. Instead, he used them to develop his own thoughts, adopting, adapting, criticizing and discarding them as he saw fit.

While entirely novel theoretical innovations from the Global South should of course be encouraged, that should not be the sole focus of those looking beyond the West for new ways to understand international relations. Such a narrow focus would run the risk of overlooking much of the important work that is being, and has already been, done. The work of scholars such as those introduced in this article clearly constitute and should be recognised as valuable theoretical contributions, and serve to disprove the claim that little innovative theoretical work is being done outside of Europe and North America.

\section{Bibliography}

Acharya, Amitav, and Barry Buzan. "Why is there no non-Western IR theory? An Introduction." International Relations of the Asia-Pacific 7, no. 3 (2007): 287-312.

Aron, Raymond. "What Is a Theory of International Relations?" Journal of International Affairs 21, no. 2 (1967): 185-206.

Aydinli, Ersel, and Julie Matthews. "Are the Core and Periphery Irreconcilable? The Curious World of Publishing in

Contemporary International Relations.” International Studies Perspectives 1 (2000): 289-303.

Ayoob, Mohamed. "Subaltern Realism: International Relations Theory Meets the Third World." In International Relations Theory and the Third World, edited by Stephanie G. Neuman, 31-54. Houndsmills: Macmillan, 1998. Bajpai, Kanti. “Obstacles to Good Work in Indian International Relations.” International Studies 46, no. 1-2 (2009): 109-28. 
Bilgin, Pinar. "Thinking Past 'Western' IR?” Third World Quarterly 29, no. 1 (2008): 5-23. doi:10.1080/01436590701726392.

Bleiker, Roland. "Searching for Difference in a Homogeneous Discipline." International Studies Review 8 (2006): 128-30.

Brown, William. “Africa in International Relations: A Comment on IR Theory, Anarchy and Statehood.” Review of International Studies 32 (2006): 119-43.

Clapham, Christopher. Africa and the International System: The Politics of State Survival. Cambridge: Cambridge University Press, 1996.

Cooper, Andrew, ed. Niche Diplomacy: Middle Powers after the Cold War. Houndsmills: Macmillan, 1997.

Cunningham-Cross, Linsay. "The Innovation Imperative: Chinese International Relations Research and the Search for a 'Chinese School'." Unpublished paper, n.d.

Dunn, Kevin, C. and Timothy M. Shaw, eds. Africa's Challenge to International Relations Theory. Basingstoke: Palgrave, 2001.

Gaylard, Rob. "Welcome to the World of Our Humanity: (African) Humanism, ubuntu and Black South African Writing." Journal of Literary Studies 20, no. 3-4 (2004): 268-82.

Geldenhuys, Deon. Deviant Conduct in World Politics. New York: Palgrave Macmillan, 2004.

— The Diplomacy of Isolation: South African Foreign Policy Making. Johannesburg: Macmillan South Africa, 1984.

Isolated States: A Comparative Analysis. Cambridge: Cambridge University Press, 1990.

Gill, Stephen. "Transformation and Innovation in the Study of World Order." In Innovation and Transformation in International Studies, edited by Stephen Gill and James H. Mittelman, 5-24. Cambridge: Cambridge University Press, 1997.

Jordaan, Eduard. "The Concept of a Middle Power in International Relations: Distinguishing Between Emerging and Traditional Middle Powers.” Politikon 30, no. 1 (2003): 165-81.

Kimmerle, Heinz. "Ubuntu and Communalism in African Philosophy and Art." Rozenberg Quarterly, September 2011. Accessed August 10, 2016. http://rozenbergquarterly.com/ubuntu-and-communalism-in-africanphilosophy-and-art/ .

Le Pere, Garth. "South Africa - an ‘Emerging Power'?” Global Dialogue 3, no.1 (1998): 1-2.

Mazrui, Ali. "On the Concept of "We are all Africans." American Political Science Review 57, no. 1 (1963): 88-97. . Towards a Pax Africana: A Study of Ideology and Ambition. London: Wakefield \& Nicolson, 1967.

Mallavarapu, Siddharth. "Theories of International Relations." In International Relations: Perspectives for the Global South, edited by Bhupinder Chimni and Siddharth Mallavarapu. New Delhi: Dorling Kindersley, 2012.

Mittelman, James H. "Rethinking Innovation in International Studies: Global Transformation at the Turn of the Millennium.” In Innovation and Transformation in International Studies, edited by S. Gill and J. H. Mittelman, 248-63. Cambridge, UK: Cambridge University Press, 1997.

Murithi, Tim. "A Local Response to the Global Human Rights Standard: The 'Ubuntu' Perspective on Human Dignity." Globalization, Societies and Education 5, no. 3 (2007): 277-86.

_ . "Practical Peacemaking Wisdom from Africa: Reflections on Ubuntu." The Journal of Pan African Studies 1, no. 4 (2006): 25-34

Nel, P., I. Taylor, and J. van der Westhuizen. "Multilateralism in South Africa's Foreign Policy: The Search for a Critical Rationale." Global Governance 6, no. 1 (2000): 43-60.

Neuman, Stephanie, ed. International Relations Theory and the Third World. Houndsmills: Macmillan, 1998.

Nkiwane, Tandeka. "Africa and International Relations: Regional Lessons for a Global Discourse." International Political Science Review 22, no. 3 (2001): 279-90.

Schoeman, Maxi. "South Africa as an Emerging Middle Power." African Security Review 9, no. 3 (2000): 47-58. - "South Africa: Between History and a Hard Place." In International Relations Scholarship around the World, edited by Arlene Tickner and Ole Waever, London: Routledge, 53-70. 2009. 
Smith, Karen. "Contrived Boundaries, Kinship and Ubuntu: A (South) African View of the 'International'." In Thinking International Relations Differently, edited by A. Tickner and D. Blaney, 301-21. London: Routledge, 2012.

"Has Africa Got Anything to Say? African Contributions to the Theoretical Development of International Relations." The Round Table 98, no. 402 (2009): 269-84.

- "Obstacles to the Development of IR Theory in the Developing World: The Case of South Africa." Africa Review 2, no. 1 (2010): 65-80.

Solomon, Hussein. "South African Foreign Policy and Middle Power Leadership." In Fairy Godmother, Hegemon or Partner? In Search of a South African Foreign Policy, edited by Hussein Solomon. Halfway House: Institute for Security Studies Monograph Series, 1997.

South African Government. "White Paper on South African Foreign Policy- Building a Better World: The Diplomacy of Ubuntu.” Accessed September 1, 2016. http://www.gov.za/documents/white-paper-south-african-foreignpolicy-building-better-world-diplomacy-ubuntu.

Swanson, D.M. "Ubuntu: An African Contribution to (Re)search for/with a 'Humble Togetherness'." Journal of Contemporary Issues in Education 2, no. 2 (2007): 53-67.

Tickner, Arlene, and David Blaney, eds. Thinking International Relations Differently. London: Routledge, 2012.

Tickner, Arlene, and Ole Wæver, eds. International Relations Scholarship around the World. London and New York: Routledge, 2009.

Tieku, Thomas Kwasi. “Collectivist Worldview: Its Challenge to International Relations.” In Africa and International Relations in the Twenty-First Century, edited by Fantu Cheru, Timothy Shaw, and Scarlett Cornelissen, 36-50. Basingstoke: Palgrave Macmillan, 2012.

"Solidarity Intervention: Emerging Trends in AU's Interventions in African Crisis." Speaking notes for the workshop on Africa International: Agency and Interdependency in a Changing World, Chatham House, London, UK, October 9, 2009.

Vale, Peter. "International Relations in Post-apartheid South Africa: Some Anniversary Questions.” Politikon 31, no. 2 (November 1, 2004): 239-49. doi:10.1080/0258934042000280751.

van der Westhuizen, Janis. “South Africa's Emergence as a Middle Power.” Third World Quarterly 19, no. 3 (1998): 435-55. 